\title{
Commentary: FISHing for the light at the ends of chromosomes
}

The discovery of the structure of telomeres having short DNA sequences $\left[\mathrm{T}_{2} \mathrm{AG}_{3}\right]_{\mathrm{n}}$ of tandem repeats and their role in chromosome stability has become the subject of scrutiny and debate. ${ }^{1-7}$ It has been known that telomeres serve as a buffer against end to end chromosome fusion and permit the complete replication of the terminal regions retaining chromosomal integrity. Chromosomes without telomeres are highly unstable and frequently lost during cell kinetics. ${ }^{2-8}$ There are numerous examples in wheat and barley, where terminally deleted chromosomes are maintained due to the addition of telomeres, ${ }^{9}$ a concept verified in human chromosomes as well. ${ }^{10,11}$ The addition of $\left[\mathrm{T}_{2} \mathrm{AG}_{3}\right]_{\mathrm{n}}$ by telomerase and acquiring a new telomere through recombination (telomere capture), are the two proposed healing pathways for terminally deleted human chromosomes. ${ }^{12}$ Knowledge concerning maintenance and regulation of telomere length is rapidly unfolding and it has become quite obvious that a chromosome will not be maintained without a functioning telomere. ${ }^{2,3,13,14}$ All of those cases with reported terminal deletions, have at least the minimum $\left[\mathrm{T}_{2} \mathrm{AG}_{3}\right]_{\mathrm{n}}$ sequences attached. ${ }^{10}$ However, in Drosophila another possible mechanism has been proposed where telomeric structures have been formed by large repeated sequences of the non-long terminal repeat retroposon without the presence of telomeric sequences. ${ }^{15,16}$

Brkanac and colleagues ${ }^{17}$ performed molecular analysis on those patients with a number of chromosome 18 specific probes including two human $18 \mathrm{q}$ telomeric probes; one contained sequences within the distal $270 \mathrm{~Kb}$ of $18 \mathrm{q}$. Their results suggest that of the 35 cases with $18 \mathrm{q}$ 'terminal deletions' five were more complex and three had 'terminal 18q sequences present.' Telomeric sequences homologous to their probe were not detected in the remaining cases. In our opinion, those remaining cases have at least the $\left[\mathrm{T}_{2} \mathrm{AG}_{3}\right]_{\mathrm{n}}$ 'cap' attached to them, possibly with the chromosome 18 specific telomere associated sequences (TAS) missing. Flint $e t a l^{11}$ characterized patients with terminal deletions on $16 \mathrm{p}$ with alpha thalassemia truncations who were stabilized with the addition of telomeric repeats but were missing any TAS sequences. Vermeesh and colleagues ${ }^{18}$ characterized telomeres in four patients with Cri du chat syndrome [del(5)(p13.3;pter)] and a patient with Wolf-Hirschhorn syndrome [del(4)(p15.1;pter)]. They too emphasized that the main mechanism of chromosome healing was due to de novo telomerase synthesis via telomerase. ${ }^{16}$ This appears to be the case and more and more data are supporting this scenario. ${ }^{10,19} \mathrm{~A}\left[\mathrm{~T}_{2} \mathrm{AG}_{3}\right]_{\mathrm{n}}$ probe can identify the "newly acquired' telomeres. If indeed the entire terminal area including the telomere is deleted but a new telomere is added for stability, would this still be considered terminal? And should it be classified with an interstitial deletion that retains just the TAS and telomeric sequences of the original chromosome? Since the ends of chromosomes have been found to be rich in transcribed sequences ${ }^{20}$ it is necessary to determine the nature of deletions, specifically since the second proposed nature of acquiring new telomeres is 'telomeric capture'. Chromosomes with terminal deletions are very frequent in human neoplasia and they are both stable and retained. A number of mechanisms have been proposed. ${ }^{12,18,21-27}$

In recent years, exhaustive literature has been generated to emphasize the importance of FISH technique using whole chromosome and loci specific probes. ${ }^{28-34}$ Nevertheless, like any other staining procedures, there are many pitfalls associated with this technology, ${ }^{35}$ and one can easily be misled while characterizing a segment of DNA containing highly repetitive sequences. For example, the alphoid sequences of centromeres do not always stain positively by FISH probes. ${ }^{35,36}$ Should we assume that because a targeted region is below detection levels by FISH techniques, it does not have a centromere? Likewise, can a chromosome exist without having a centromere? Obviously, the resolution of certain probes is not high enough to detect the presence of all centromeres, which can equally be true for highly polymorphic TAS and telomere sequences. ${ }^{37,38}$ Recent advances in peptidenucleic acid (PNA) based technology can be used to produce FISH probes for telomerase sequences. Hopefully, PNA probes will be able to detect the unique $\left(\mathrm{T}_{2} \mathrm{AG}_{3}\right)_{\mathrm{n}}$ sequences and may also address the above 
problem. ${ }^{39}$ Numerous articles suggesting there are no telomeres present on deleted chromosomes have clearly challenged a very fundamental concept of chromosome stability! Nevertheless, in our experience, terminally deleted chromosomes have retained/healed the terminal ends with telomeres. It is the telomeres which retain chromosomal integrity; as both Muller ${ }^{40}$ and McClintock $^{41}$ knew long ago, all cannot be well unless chromosomes end well.

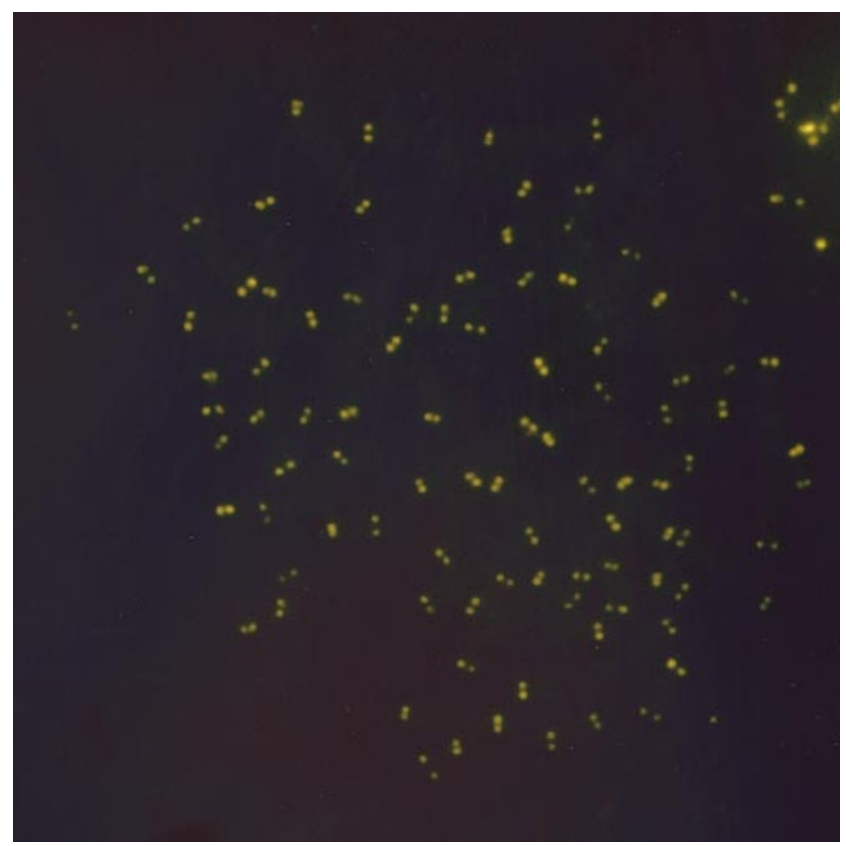

Figure 1 Human telomeres detected with PNA (peptide nucleir acid) probe for the telomere repeat sequence (courtesy of E. de Pauw, Department of Molecular Cell Biology, Leiden University Medical Centre, The Netherlands).

Ram S Verma ${ }^{1,2}$ Michael J Macera ${ }^{2}$

${ }^{1}$ Division of Molecular Medicine and Genetics Wycokoff University Medical Center, Brooklyn, and New York Hospital/Cornell Medical Center, New York, USA

${ }^{2}$ Institute of Molecular Biology and Genetics and SUNY Health Science Center, Brooklyn, New York, $U S A$

\section{References}

1 Giulotto E, Mondello C: In: Verma RS (ed.). Advances in Genome Biology: Genes and Genome, JAI Press: Greenwich, CT, 1998, vol 5B, pp 323-361.

2 Kipling D (ed.): The Telomere. Oxford University Press: Oxford, 1995.

3 Brenner S: Telomeres and Telomerase, Wiley and Sons: New York, 1998.

4 Wellinger RJ, Ethier K, Labrexque P, Zakian VA: Evidence for a new step in telomere maintenance. Cell 1996; 85: $423-433$.

5 Biessman H, Mason JM: Telomere maintenance without telomerase. Chromosoma 1997; 106: 63-69.

6 Slijepcevic P: Telomeres and mechanisms of Robertsonian fusion. Chromosoma 1998; 107: 136-140.

7 Zakian VA: Telomeres: beginning to understand the end. Science 1995; 270: 1601-1607.

8 Zakin VA: Life and cancer without telomerase. Cell 1997; 91: $1-3$.

9 Werner JE, Kato RS, Gill BS: Distribution of telomeric repeats and their role in the healing of broken chromosome ends in wheat. Genome 1992; 35: 844-848.

10 Guo W-J, Callif-Daley F, Zapata MC, Miller ME: Clinical and cytogenetic findings in seven cases of inverted duplication of $8 \mathrm{p}$ with evidence of a telomeric deletion using fluorescence in situ hybridization. Am J Hum Genet 1995; 58: 230-236.

11 Flint J, Craddock CF, Villegas A et al: Healing of broken human chromosomes by addition of telomeric repeats. $A m$ J Hum Genet 1994; 55: 505-512.

12 Meltzer PS, Guan X-Y, Trent JM: Telomere capture stabilizes chromosome breakage. Nat Genet 1993; 4: 252-255.

13 Slijepcevic P, Bryand PE: Chromosome healing, telomere capture and mechanisms of radiation-induced chromosome breakage. Int J Radiat Biol 1998; 73: 1-13.

14 Linger J, Cech TR: Telomerase and chromosome end maintenance. Curr Opin Genet Devel 1998; 8: 226-232.

15 Melek M, Shippen DE: Chromosome healing: spontaneous and programmed de novo telomere formation by telomerase. Bioassays 1996; 18: 301.

16 Leuis RW, Ganesan R, Houtchpns K, Tolar LA, Sheen F: Transposons in place of telomeric repeats at a Drosophila telomere . Cell 1993; 75: 1083-1093.

17 Brkanac Z, Cody JD, Leach RJ, DuPont BR: Identification of cryptic rearrangements in patients with $18 \mathrm{q}$ deletion syndrome. Am J Hum Genet 1998; 62 $1500-1506$.

18 Vermeesch JR, Falzetti D, Van Buggenhout G, Fryns JP, Maryanen P: Chromosome healing of constitutional chromosome deletions studied by microdissection. Cytogenet Cell Genet 1998; 81: 68-72.

19 Lamb J, Harris PC, Wilkie AOM, Wood WG, Dauwerse JHG, Higgs DR: De novo truncation of chromosome 16p and healing with (TTAGGG) $)_{n}$ in the alpha thalassemia/ mental retardation syndrome (ATR-16). Am J Hum Genet 1993; 52: 668-676.

20 Saccone S, De Sario A, Della Valle G, Bernardi G: The highest gene concentrations in the human genome are in telomeric bands of metaphase chromosomes. Proc Natl Acad Sci USA 1992; 89: 4913-4917. 
21 Wang S-S, Zakian VA: Telomere-telomere recombination provides an express pathway for telomere acquisition. Nature 1990; 345: 456-458.

22 Morin GB: Telomere integrity and cancer. J Natl Cancer Inst 1996; 88: 1095-1096.

23 Ning Y, Liang JC, Nagarajan L, Schrock E, Reid T: Characterization of $5 \mathrm{q}$ deletions by subtelomeric probes and spectral karyotyping. Cancer Genet Cytogenet 1998; 103: $170-172$.

24 Nugent CI, Bosco G, Ross LO, Evans SK, Haber JE, Lindblad V: Telomere maintenance is dependent on activities required for end repair of double-strand breaks. Curr Biol 1998; 8: 657-661.

25 Rowley PT: Telomerase: Putting an end to DNA. Cancer Invest 1998; 16: 170-174.

26 Bryan TM, Englezou A, Dalla-Pozza L, Dunham MA, Reddel RR: Evidence for an alternative mechanism for maintaining telomere length in human tumors and tumorderived cell lines. Nat Med 1997; 3: 1271-1274.

27 De Lange T: Telomere dynamics and genome instability in human cancer. In: Blackburn IH, Greider CW (eds). Telomeres. Cold Spring Harbor Laboratory Press: New York, 1995, pp 265-293.

28 Verma RS, Babu A: Human Chromosome: Principles and Techniques. McGraw-Hill: New York, 1995.

29 Verma RS, Batish SD, Ramesh KH, Gogineni SK: Are we FISHing in troubled waters? Cell Mol Biol Res 1995; 41: 81-84.

30 Neslinger NJ, Gorski JL, Kurczynski TW, et al:: Clinical, cytogenic, and molecular characterization of seven patients with deletions of chromosome 22q13.3. Am J Hum Genet 1994; 54: 464-472.
31 Precht KS, Lese CM, Spiro RP, et al.: Two 22q telomere deletions serendipitously detected by FISH. J Med Genet 1998; 35: 939-942.

32 Kurenova EV, Mason JM: Telomere functions: A review. Biochemistry (Mosc) 1997; 62: 1242-1253.

33 Urquidi V, Tarin D, Goodison S: Telomerase in cancer: clinical applications. Ann Med 1998; 30: 419-430.

34 Bertuch A, Lundblad V: Telomeres and double-strand breaks: trying to make ends meet. Trends Cell Biol 1998; 8 339-342.

35 Verma RS, Luke S: Variation of alphoid DNA sequences escape detection of aneuploidy at interphase. Genomics 1992; 14: 113-11.

36 Verma RS, Batish SD, Gogineni SK, Kleyman SM, Stetka DG: Centromeric alphoid DNA heteromorphism of chromosome 21 revealed by FISH-technique. Clin Genet 1997 51: $91-93$

37 Burr B, Burr FA, Matz EC, Albertsen MC, Stuber CW: Pinning down loose ends: mapping telomeres and factors affecting their length. Plant Cell 1992; 4: 953-960.

38 Biessmann H, Manson JM: Telomeric repeat sequences. Chromosoma 1994; 103: 154-161.

39 Senior K: Going FISHing with peptide nucleic acid. Mol Med Today 1998; 4: 231.

40 Muller HJ: The remaking of chromosomes. Coll Net 1938; 8: $182-195$.

41 McClintock B: The stability of broken ends of chromosomes of Zea mays. Genetics 1941; 26: 234-282. 